\title{
Historicity and Storytelling in East Timorese Fiction in Portuguese
}

\author{
Isabel Moutinho \\ La Trobe University, Melbourne, Australia
}

\begin{abstract}
This article analyses the interplay between historicity and a uniquely Timorese style of storytelling in the work of three diasporic writers from Timor-Leste: Luís Cardoso, Ponte Pedrinha and Domingos de Sousa. It provides a brief overview of the contemporary Timorese literary landscape and speaks to the coexistence of and links between tradition, fiction and history. It highlights the historical dimensions of storytelling in works that dialogue dynamically with the traditional narrative forms and the Timorese imaginaire, as their authors write Timor-Leste into history.
\end{abstract}

Keywords: Timorese literature (in Portuguese); fiction; history; storytelling; historicity; Timorese social life and customs; Timorese languages; Timorese myths; oral tradition.

Timor-Leste has a centuries-old vernacular oral tradition, a characteristic the tiny half-island country shares with many other nations in the region. Fortunately, missionaries and priests recorded at least a fraction of its oral cultural heritage. Artur Basílio de Sás 1961 anthology of oral literature in Tetum makes some such texts available. More recently, for his 2007 dissertation, Nuno da Silva Gomes transcribed and translated into Portuguese twenty-one oral texts from the Tetum tradition. He presents a selection of ai-knanoik (folk tales, legends or fables, in prose or verse), ai-knananuk (songs, verses to be sung at traditional parties) and hamulak (narrative poetry or prayers, to be performed solemnly in ritual ceremonies). Apart from a few such collections, however, oral literature is of difficult access outside the country, not least because of lack 
of linguistic expertise amongst foreign researchers either in Tetum, the ritual language of poetry, or any other of the East Timorese national languages.

Undoubtedly, poetry is still the favourite means of literary expression for the East Timorese. Writing in Portuguese, Fernando Sylvan (d. 1993), Francisco Borja da Costa (d. 1975), João Aparício and Xanana Gusmão are the most recognized poets, with several books in print and work included in anthologies (Moutinho, "New Dawn"), but others who write in Tetum, Portuguese, or Indonesian publish their work in the Saturday edition of the local Timor Post, or in numerous blogs (Lipscomb 168). Abé Barreto Soares is the best-known name in his generation, for his poetical output, his scholarship on poetry, and his leadership role in a circle of young poets whose work is available on line.

As for literary prose, its emergence in Timor-Leste has been much slower. Nevertheless, it could not have had a more auspicious beginning than the publication in 1997 of Luís Cardoso’s Crónica de Uma Travessia. A Época do Ai-Dik-Funam, translated into French, English, German, Italian, and Swedish. Luís Cardoso has since published three novels, with a fourth one already finished and due out in 2013. He is no longer the only novelist from Timor-Leste, but the sustained literary excellence of his output inevitably casts shadow on the work of two other writers. Ponte Pedrinha's novel Andanças de Um Timorense appeared one year later (1998), and Domingos de Sousa published his Colibere: Um Herói Timorense ten years after Cardoso's Crónica de Uma Travessia. The three authors have in common their choice of Portuguese as their literary language.

This is not to say that there is no literary prose being written in Tetum, the national language of Timor-Leste inscribed in the Constitution as co-official, together with Portuguese. ${ }^{1}$ Câncio Ximenes and Hugo Fernandes are both poets and short story writers; Merio (or Almerio) too has written a number of stories; but these are not yet in print. More promising still is the significant incentive that the inauguration of a national short novel writing competition, the "Kompetisaun Istoria Timor,"2 has given to fiction writing in Tetum, which has already led to the publication, in 2009, of the winning entry, Teodósio Ximenes's Ha'u Maka Lucas [I am Lucas]. The following call for entries saw first prize being attributed to Iha Nafatin Dalan Atu Fila [The Same Way 
to Return], by Maximus Tahu, and to Cidália da Cruz's Mesak Katak Nonook [Solitude Means Silence] as best story by a woman (Istoria-Timor).

Although this brief introduction to East Timor's literary scene is indispensable, it is nevertheless not the aim of this study to focus either on poetry (in Tetum or in Portuguese) or on the emerging prose written in Tetum by authors of a younger generation. ${ }^{3}$ Instead, this study concentrates on the novels written in Portuguese by three Timorese authors, diasporic writers as it happens, but whose work remains very deeply rooted in a strikingly Timorese imaginaire. All three, in very different ways, share a common feature: the combination of a strong concern with historicity with various, and distinctive, styles of storytelling. Historicity means here their patent desire to bear witness to TimorLeste's tragic history in the late twentieth century, which determined both their country's and their private destinies: the three were born in then Portuguese Timor, and the three were forced into exile by the sudden Indonesian invasion of $1975 .{ }^{4}$ As to their interest in storytelling, it may well respond, to some significant extent, to their deep-rooted familiarity with the oral narrative tradition of their country of birth. Furthermore, although some of Luís Cardoso's novels display elements common to historiographic metafiction, as defined by Linda Hutcheon, all these books present very salient characteristics that distinguish them from postmodernist writing, and which, I argue, emanate from and simultaneously constitute their Timorese specificity.

To begin simply in chronological order, Luís Cardoso's 1997 Crónica de Uma Travessia [The Crossing] was immediately celebrated in Europe as the first book by a Timorese author (even as the first Timorese novel, although it is, in fact, not a novel; the author's subsequent titles are definitely novels). This is, therefore, the least fictional of the books here examined. As often happens with works by authors from previously colonised countries, Crónica de Uma Travessia is a life-story, indeed a double one: the author's, who identifies himself by a nickname he still uses (Travessia 87 ), together with his father's, intertwined with plentiful recollections of life in colonial Timor, thus combining the autobiographical register with the memoir. Historical background is crucial throughout the book. Cardoso explains that his father was "a committed and diligent servant of the [Portuguese] empire" (2), ${ }^{5}$ and a UDT supporter; 
he was arrested by Fretilin during the civil war that broke out in 1975 between newly formed Timorese political parties, following an attempted coup by UDT, which Fretilin withstood. ${ }^{6}$ Disrupting chronology, Cardoso then recalls the 1910-1912 Manufahi wars, the largest of many sporadic revolts against Portuguese rule, which the colonial forces eventually crushed, not without considerable difficulty. For this reason, the Manufahi war has remained a powerful symbol of Timorese resistance. Its inclusion, however, does more than provide historical background alone: "The official historians attribute the revolt to $[\ldots]$ that rebellious liurai, who refused to pay levies and taxes to the region's protector" (5). It also contrasts that official explanation with "the stories and rumours going around the villages" (5), according to which the cause of the war was the Portuguese military commander's being besotted with the rebellious liurai’s wife, enticingly described as "aquele feitiço feito mulher indígena" (Travessia 15) [sorcery turned indigenous woman]. This, then, already brings out the interplay between historicity and storytelling, but with the added dimension that whereas the official histories are written in European languages, the stories belong to the indigenous oral tradition and incorporate local beliefs and rumours. Such stories would resonate especially with Timorese readers, although for the time being this involves other difficulties, as it necessitates a reading proficiency in Portuguese, which is not yet widespread in the young nation.

To be sure, the historical dimension is pivotal in this book. But actually two historical perspectives are involved: the linear, chronological one (referring to the Portuguese administration, Portugal's democratic revolution, the emergence of political parties and the outbreak of civil war in Timor, and the exodus-for the fortunate ones who managed to escape the horrors of the Indonesian invasion); and the autochthonous, ancestral one, that of the narrator's father, which a reader not familiar with the Timorese worldview may overlook. Indeed, the author's father, who remains faithful to the Portuguese empire until he dies, obeys the ideal of mate-bandera-hun (Tetum for to die in the shade of the Portuguese flag, often revered as sacred, lulik). This can easily be read as magical realism, as an addition of local colour, or simply as a reminder of what became the slogan of pro-Portuguese UDT. But in fact it also represents-in Luís Cardoso's characteristically understated style-a significant aspect of the 
Timorese conception of the world. The author's brief biography included in the book mentions that his father was a Mambai-speaker. The Mambai are "the eldest folk on Timor" (Traube, Cosmology 51). According to them, Timorese liurais were not humiliated by the Portuguese administration; rather, their power "emanated" (Traube, Cosmology 52) from the colonial rulers who had arrived centuries earlier. It is worth quoting an excerpt from Elizabeth Traube's study of Mambai cosmology, which makes the reasons for the elderly father's devotion to the Portuguese empire very clear:

By Mambai theories of origin, the Malaia [all non-Timorese, particularly the Portuguese], who occupy the structural position of outsider-rulers, are not strangers at all, but are the returning younger sons of the land. The ultimate origins of the Malaia are autochthonous, their relationship to the Timorese is based on kinship, and their arrival on Timor signifies the return of the legitimate defenders of order. (Traube, Cosmology 53)

This, of course, is very likely a mythical invention after the fact of the establishment of Portuguese rule. Nevertheless, it is also the time-honoured world order that the elderly father believes many younger Timorese have somehow transgressed, for which they deserve the "accusing finger" (144) he points, towards the end of the book, at his son's generation. The world order, invented or otherwise, "that encompasses colonial rule" should not be transgressed, and those who "disregard that order" deserve "moral condemnation" (Traube, Cosmology 64).

On the other hand, although this is not a fictional work, Cardoso takes pride in narrating how he became a storyteller. As a child, he listened spellbound to the Biblical stories that the boyfriend of one of his cousins used to embellish for the benefit of his listeners. One day the boy had an opportunity to steal the young man's Bible, finding photographs of "white naked women" in it, which he took to be of "Eve, naked, covering her breasts and her postvirginity" (34). And with this theft he "inherited the book and the stories [...] Stories to make people weep and that blamed the ancestors for their children's current misfortunes" (34). Not wishing to detract from the enjoyment of a very readable translation, the English version of this passage does, however, rob the 
original of one important implied meaning. What the Portuguese original says is "Fiquei dono do livro e das histórias que passei a contar" (Travessia 42) [I became the owner of the book and of the stories, which I started to tell], obliquely pointing to the lia nain, the owner of words. This Tetum word that appears in many of Cardoso's books often describes a traditional arbitrator of disputes, or a ritual speaker at a ceremony. But the owner of words is also the traditional verse and storyteller, who receives oral texts from the elders, commits them to memory, and then retells them. With a slightly different focus, the English translation successfully conveys the process of oral transmission by which a storyteller inherits the elders' knowledge. But, in addition, by choosing an unusual formulation in Portuguese, Luís Cardoso delicately presents his credentials, signalling the difference of his cultural tradition and his style of storytelling.

As such, references crop up that surprise in a mostly non-fictional book: sharks around the island of Ataúro only attack people who "ha[ve] offended some custom, creature or ancestor" (15); Cardoso's mother fears the Pontiana, or the spirit of seduction (26); going near a swamp where "spirits [...] who kidnapped people" lurk is dangerous (67); carrying eggs in one's pocket to give to the eels in spring (115); or the need to counteract the rain-fila, the tricks the earth plays on humans, by putting one's clothes on back to front to find one's way home (121). Only a few pages later, though, the book starts detailing the actions of Colonel Alves Aldeia, the last military Governor, during the final years of Portuguese rule (1972-1974) that saw the beginning of the decolonisation process and the formation of Timorese political parties. The following chapters also bring to life the activities of those who were then the minute educated elite, about to become Timor-Leste’s political leaders: José Ramos-Horta, the Carrascalão brothers, Mari Alkatiri, Nicolau Lobato, Osório Soares, Xavier do Amaral, and later Xanana Gusmão. Luís Cardoso writes also of Venâncio (Gomes da Silva, presumably) and Abílio Araújo amongst others as very familiar figures. The small number of schools in Portuguese Timor meant that most students knew each other, with many having gone through the Soibada Catholic mission school, and then on to the Dare seminary—so that they were, "above all, ex-seminarians" (100).

Crónica de Uma Travessia is a book of contrasts: the childhood recollections are witty and full of tenderness, with a fairy tale feel about them; real-life 
friends, acquaintances, and public figures are described with gentle humour; but the pages devoted to the country's contemporary history are a sombre meditation on what the future may bring. Surprisingly, too, a vague sense of guilt traverses them, as when the son imagines his father and his elderly friend accusing the younger generation: "What did you do to us, to yourselves, to the people we left alive and well in your hands?" (144). The Crossing offers a plethora of references both to the autochthonous ancestral culture and to the Portuguese-Timorese way of living, cemented over centuries, which later appears repeatedly in Cardoso's fictional prose. But there is something else the book does very powerfully: through the loving enumeration of place names, all the places father and son passed through affectionately recalled, it literally draws a map of Timor through words and images - a map that goes well beyond Dili to include many remote Timorese villages. Concerned with historicity it is, but geography plays an equally important role, as the title clearly indicates. Above all, it is in the chapters devoted to the remembrance of the author's childhood that the voice of the storyteller begins to soar: an extraordinary writer is born.

The second book published by a Portuguese-speaking Timorese writer is Ponte Pedrinha's novel, Andanças de Um Timorense [Perambulations of a Timorese], of 1998. ${ }^{7}$ Just like Cardoso's Travessia, it was written towards the end of the Indonesian occupation, well before any hope of even a referendum began to shine. Its pessimistic, almost lugubrious atmosphere is therefore not surprising. The novel's structure is somewhat challenging. It begins with a twopart chapter that reads more like a separate story ("Um timor sem cidade," a Timorese without a city), not very successfully incorporated, which turns out to serve a double function: to pinpoint the moment when the narrator becomes a writer and to give the reader some insight into his psychology. Thereafter the reader realises that the protagonist is probably the author of the previous short story; he had been separated from his parents in infancy, as a consequence of the misfortunes that befell the young couple after they refused to follow an ancestral practice of Ataúro island: that the bride be deflowered not by her husband, but by his youngest uncle (Esperança 47). Now named Samuel, the protagonist was born in Timor but was soon orphaned ("de pai, mãe e pátria," 148 [bereaved of father, mother and homeland]), taken to Darwin, Australia, as a child, in a move 
intended to save him from the Indonesian carnage, raised by a priest, and later taken to Portugal, where he grew up with a strong Catholic faith and where he becomes a writer before leaving for missionary work in Africa.

The novel reveals equal concerns with historicity and storytelling, but both preoccupations sway according to a strongly Timorese undercurrent. The fact that the narrator insists on the central character ("the man") being simply "a Timorese without a city" $(7,87,88$, etc.) indicates that we are dealing with a collective representation of the Timorese people. Not forgetting the plight of those who had no escape and bore the brunt of the Indonesian invasion, the focus is on anonymity and the imagery of homelessness, separation, rupture and loss of identity of exiles. Furthermore, as a leitmotiv, there are also potent feelings of guilt-much more paralysing than the subtler, and restrained, sense of culpability detectable in Luís Cardoso's meditation on Timorese destinies in Travessia. For a Western reader cognisant of the atrocities in Indonesian occupied Timor, such feelings may appear dislocated, since guilt should haunt the perpetrator, not the victim. Nevertheless, this is a poignant representation of overpowering emotions similar to those experienced by Holocaust survivors, in the kind of "inversion effect" that Inga Clendinnen analyses (185). As the central character in Andanças de Um Timorense puts it: "tantos heróis e tantos mártires, um povo traído e eu calado" (26) [so many heroes and so many martyrs, a people betrayed and I remain silent]. His almost self-annihilating feelings of guilt thus relate to an inability to tell the tragic history of his fellow Timorese, precisely the inability he conquers at the beginning of the novel when after a night of tormented writing he completes his first short story ("rematou o seu primeiro conto" 11). This becomes the novel's point of departure.

The notion of historicity here is certainly different from that in the realist historical novel as characterized by Georg Lukács. Andanças does tell a story that has "broken with the tendencies which make history private" and one that is "deeply connected from the very beginning with the fortunes of the people, socially and humanly" (Lukács 282); but the particular twist the narrator gives it, by portraying the central character's deep religiosity, sense of mission and spirit of sacrifice, creates a disproportion between historicity and individual idiosyncrasy that might detract from historical representation. Then again, 
although initially intensely self-reflective, this novel never really becomes postmodernist historiographic metafiction: there is no parody, no intertextual play, no problematising of history (Hutcheon).

Instead, an intense Timorese imaginaire permeates the novel, through which historicity and storytelling amalgamate. It could be argued that the tone is too moralistic, too Biblical, for a novel really concerned with historical reality-except that in Timor religion is an integral part of history, as are myth and legend. Here it is indispensable to retain the crucial historical role of the Catholic Church in the half-island: originally a foreign religion imposed by the coloniser, Catholicism became the banner under which the East Timorese rallied against enforced Indonesianisation, when they chose familiar Christianity over alien Islam (even if only because Animism is not one of the five religions the Indonesian pancasila recognises), and finding no other refuge-spiritual and even physical - than in their faith and churches in their darkest hour. Moreover, it was largely because the Timorese Catholic clergy applied to the Vatican for a special dispensation to adopt Tetum as the liturgical language, after Indonesia forbade the use of Portuguese, that Tetum gained increasing prestige and later became the national language, despite not necessarily being the most widely spoken in Timor at the time. ${ }^{8}$

If historicity means primarily the historical and social reality of a people, then Christianity is at the heart of Timor-Leste's history: in the development of the country's national language and its national identity, as well as through the Timorese bishops' indefatigable efforts to draw attention to the plight of their people. Simultaneously, Christianity is also at the core of Timorese storytelling, because the Bible's parables have captured the imagination of a people accustomed to listening to stories, and whose ancestral knowledge is carried orally and precisely through storytelling.

It is interesting that Luís Cardoso, too, a writer who does not otherwise reveal much religiosity, and in whose work Animist and Catholic practices often coexist as part of a childhood enchanted realm, does make a point of tracing the beginning of his storytelling vocation to the stories of the Bible-though in characteristic tongue-in-cheek Cardoso style perhaps more because of the sexuality of the actors involved in the original sin than in the actual dogma. 
The most impressive novels from Timor-Leste written in Portuguese are unquestionably Luís Cardoso's four fictional titles to date: Olhos de Coruja Olhos de Gato Bravo (2001). A Última Morte do Coronel Santiago (2003), Requiem para o Navegador Solitário (2007), and O Ano em que Pigafetta Completou a Circum-Navegação (forthcoming in 2013, not included in this study). All blend historicity and storytelling deftly and beguilingly.

Olhos de Coruja Olhos de Gato Bravo [Owl's Eyes Wild Cat's Eyes] immediately plunges the (Western) reader into a very unfamiliar culture, where traditional Timorese beliefs take central place, and the factual and the spiritual coexist in daily life. Olhos de Coruja is again a life-story, but unlike Travessia, it is a purely fictional work. In contrast, too, to the author's first book, here the narrator is a girl, born to elderly parents who already have twin sons. Her father is a catechist of mixed Chinese and Timorese blood, and her mother, a woman of European and Timorese parentage. The girl is born with huge owl-like eyes, which leads to her father's rejection of the baby, for he feels threatened by this excess (131). At her baptism, the priest covers her eyes with a blindfold that she must never remove. After her mother's disappearance, accompanied by her aunt, the girl undertakes a long voyage to Lisbon. Her time in Portugal is often spent with Father Santa, the priest who blindfolded her, a supporter of Portugal's Salazar regime. ${ }^{9}$ On the return voyage to Timor, after fifteen years overseas, she meets a lieutenant with wild-cat-like green eyes (118). Back home, the son of Manumasin's régulo [chieftain] expects to marry her, but when five years later the lieutenant reappears in Timor as the now Portuguese local administrator, she marries him. Eventually, she dares to remove her blindfold: "Não consegui ver nada. Foram muitos anos de sombra" (159) [I couldn’t see anything. There had been many years of darkness].

Subtle historical references permit the internal dating of this novel. One date only is registered, that of March 1974, hinting that the green-eyed lieutenant may have been involved in the attempted military coup against the dictatorship in Portugal, which although aborted led to the successful democratic revolution the following month. This, again, is the crucial time of the founding of political parties in Timor. This novel, then, covers approximately the same historical period as the events narrated in Travessia. However, the language has 
completely changed. Names are a case in point. In Travessia, real-life figures bear their actual names. For example, the narrator speaks of Domingos Oliveira, "one of the great Timorese thinkers," whom Francisco Lopes da Cruz and Paulo Pires joined to constitute "the UDT trinity from Soibada;" Xavier do Amaral, "with his aura of Western culture," united with Nicolau Lobato and Ramos-Horta, and "thus Soibada also spawned the nationalist troika;" Osório Soares, "still looking for windmills," with his brother-in-law Domingos Pinto, formed "the APODETI duo" (The Crossing 104-5). These are the real founders of their respective parties, whose common educational trajectory via the Soibada mission school Cardoso emphasises wittily, as might be expected in a book very focussed on the impact of education in colonial Timor. When the same period is mentioned in Olhos de Coruja, historical accuracy definitely comes second to storytelling: the lieutenant adheres to the "Partido Federalista" (corresponding to the UDT), where soon thereafter he meets a female fellow party member, with domestic consequences leading on to further trouble when he kills "some militants of the Independence Party” (Olhos 156-7). And the girl's long-lost father returns from Koepang, Indonesian West Timor, where in the meantime he became a businessman, to found the "Unionist Party" (157), i.e. APODETI. Those familiar with the history of Timor-Leste will recognise the parties and the outbreak of the civil war, but all is mentioned in passing, for historical realism has no place in this story.

Instead, the novel recalls many of the Timorese ancestral beliefs and customs that the protagonist leaves behind when taken to Portugal: the importance of fire, associated with life (Therik 79), in birth rituals (Olhos 23); the areca palm and betel nut chewing, particularly when women get together, or to help a bride to socialise (Olhos 59, 147); the belief in the rain-fila already mentioned in The Crossing; the existence of sacred sites where the spirits of the dead roam free; ${ }^{10}$ marriage as a means to establishing family alliances after wars; allegiance to local kings; dowry payments in buffalos; cockfighting as recreation and source of income. These constitute the fabric of traditional Timorese society, in which long-established social practices such as these have endured over the centuries and continue even today, at least in the rural areas.

As to Timor's contemporary history, it permeates the novel, but allegorically, especially given its fictional point of departure-the girl's blindfolding, 
which signifies political quietism and the distortion imposed on Timor's traditional worldview by prolonged coexistence with Portuguese culture. But as this novel concentrates on Portuguese Timor, the Catholic Church's role is different from what it became later as a pillar of resistance against Indonesian occupation. Father Santa supports Salazar's regime, as did much of the clergy at that time, so that his action symbolises the obscurantism the conservative clergy foisted on Timor's (and Portugal's) population. Besides, there seems to be an attempt to indicate some similarity of experience between the Timorese and the Portuguese people: à propos of the Portuguese military's doubts regarding their country's past deeds, the narrative voice conciliates: “Também tinham de confiar nos feitos dos seus antepassados. Negar a própria história seria a mesma coisa que apagar as marcas do homem no tempo" (Olhos 124) [They (the Portuguese) also needed to believe in their ancestors' exploits. To deny one's history would be tantamount to erasing man's imprint on time]. Can this still be the girl's voice? It sounds rather like an authorial comment on a nation's role in creating its history and the need to preserve it, at a time when Portugal began to experience the need to critique its history, and Timor was discovering the urge to reclaim its agency and to preserve its memory.

In this novel, the awakening of the narrator's storytelling vocation is traced back to the European tradition, as befits a character raised far from her native Timor. In Lisbon, the girl has a certain Madame Guimart as her tutor, so that mixed French and Portuguese influences push her toward a love of stories. Saying that "o mundo era feito de constantes mudanças" [the world is made of constant change] (an obvious echo of one of Camões' most famous sonnets), she reveals her entry into the world of literature, and Madame Guimart "foi-[lhe] enchendo a cabeça de contos de bichos, de fadas e do Principezinho" (130) [filling [her] head with stories of animals, fairy tales, and the Little Prince]. Raised abroad, away from the gatherings of Timorese women where stories are usually told by women and for an audience of mostly women and children, internal logic requires that this character derive her passion for stories from a European tradition - and from a woman. Nevertheless, the story she tells of herself and her family is profoundly steeped in Timorese culture. And the blindfold, which can be interpreted as a symbol of cultural distortion 
and obscurantism, is of course also the perfect device to highlight the orality of the Timorese tradition. When the girl's mother disappears, an aunt replaces her, but before voyaging to Portugal she too must first be baptised, so that she can obtain a passport, and learn to read and write, ${ }^{11}$ which allows her to read stories out loud to the girl: "lia-me os livros da Madame e lia os livros do padre Santa" (127) [she would read to me Madame's books and read Father Santa's books], thus adding to the girl's repertoire of Biblical stories many others from the European tradition, which she hears but cannot read.

Luís Cardoso's following novel, A Última Morte do Coronel Santiago (2003), tells the story of Colonel Pedro Santiago, who believes he was knighted in the city of Santiago de Compostela. He is a "coronel de segunda linha" [second line colonel], i.e. he has the honorary rank Portuguese colonial authorities generally awarded a "loyal" Timorese liurai. ${ }^{12}$ His story is narrated by his son, Lucas, a writer who lives in Portugal and who falls in love with Beatriz, the heroine of Luís Cardoso's previous novel. There is certainly a strong autobiographical element in A Última Morte, whose plot broadly approximates the father-and-son life-story narrated in Crónica de Uma Travessia. But this is a highly elaborate and innovative work of fiction, packed with intertextual references both to the author's previous books and to the work of many European and Latin American writers, musicians, song-writers, and film directors. Most striking amongst these, though not mentioned explicitly, are the echoes of Gabriel García Márquez’s El coronel no tiene quien le escriba, which Luís Cardoso explains in a 2010 interview, ${ }^{13}$ and Crónica de una muerte anunciada, for the foretelling of the colonel's death in the title, which comes to confirm the death of the father figure so present in Cardoso's previous books (Moutinho, "Fractured Affair"). A Última Morte invites reading in postmodernist key, for its use of intertextuality, its self-reflective quality and its preoccupation with rewriting history. But Lucas is also unmistakably a postcolonial narrator and protagonist, in his meditation on his own hybridity and his non-belonging (Tutikian).

The question then is what gives this novel its distinctive Timorese quality, despite being somewhat affiliated in Western postmodernism. In A Última Morte the colonel has a double, Pedro Raimundo, his alter ego and shadow, who takes it upon himself to right history's wrongs by killing colonel Pedro 
Santiago-just as in Olhos de Coruja Tio Benvindo, the girl's father's double, wishes him dead. And as Jane Tutikian (153) points out, in A Última Morte Luís Cardoso, the author, functions as the double of his narrator, Lucas. Cardoso is fond of constructing his fiction on binary counterparts, which are particularly striking in Olhos de Coruja, a novel profoundly imbued with Timorese imagery. In it, as already mentioned, doubles proliferate: the catechist father and the blindfolding priest; the godson "Pantaleão o Manumeta" and the uncle "Benvindo o Manumera" (Olhos 112); the mother and the aunt; Tia Matilde and Madame Guimart; the twins, Mateus and Matias; the horses, Gentio and Vadio; as well as the constant play on light and darkness, Catholicism and Animism, and so on. In A Última Morte, apart from the two Pedros, and the duo implied in Lucas Santiago, "author-narrator" and "authorial representation of Cardoso" (Tutikian 150), there are also other doubles: Pontiana and Uma Thurman; Pontiana and Beatriz; Clara driving a car blindfolded and the intertextual Beatriz; Lucas's "reactionary" character, Sexta-Feira (as in Daniel Defoe's Friday), as opposed to the exiled champions of the Timorese cause; the rank of "militar de segunda linha," implying a higher hierarchy amongst the Portuguese military (17); being born in Lorosae [Timor of the Rising Sun] and dying in Finisterre (35). These are more literarily wrought than the doubles in Olhos de Coruja, but equally perceptible.

While this recurrent representation of doubles invites identification of the feature as a sign of postcolonial hybridity, it is important to point out that there is another layer of meaning, deeply rooted in the Timorese universe, behind it. It is worth quoting an illuminating passage from Traube's study of dualism, exchange and hierarchy amongst the Mambai of East Timor:

Since van Wouden's pioneering study [1935], eastern Indonesian peoples have been associated in the anthropological literature with a pervasive or ubiquitous principle of complementary dualism. The Mambai are no exception. Their collective representations attest to an abiding cultural concern with complementarity. Whether at the level of society or of the encompassing cosmos, order is insistently defined as the product of a balance of opposites, and a scheme of interrelated dual categories [...] is brought to bear in constituting meaningful relationships. (Traube, "Obligations" 322) 
Bearing in mind that Luís Cardoso is the son of a Mambai, this leaves room for arguing that the dualism so palpable in his fiction is not only a reflection of postcolonial awareness of cultural hybridity but indeed the manifestation of a deeply rooted way of perceiving the world according to Mambai epistemology. The conspicuously ubiquitous binaries in his fiction must correspond to the intrinsic "proliferation of particular dual structures that regulate diverse realms of social life" (Traube, "Obligations" 322) amongst the Mambai. This does not mean that the writer's concern with historicity diminishes in A Última Morte. Indeed the novel strongly engages both with Portuguese colonialism and with Indonesia's threat to Timorese life and culture, as well as with the plight of Timorese exiles in Portugal. It simply means that the author's critique of history again has two dimensions: one derived from the European tradition, the other from his people's ancestral knowledge, both informing a uniquely Timorese style of storytelling.

Set just before the Japanese invasion of Timor during World War II, Cardoso's third novel, Requiem para o Navegador Solitário [Requiem for the Solo Sailor] (2007), deals with this earlier historical period. While the Japanese occupation was relatively brief (1942-1945), it nevertheless marked an important moment in the country's history because Timor was liberated by Australian troops. The help then provided by many Timorese allowed for a tradition of friendship to develop, which regrettably Australia betrayed in the mid-1970s by supporting the Indonesian aggression.

Like Olhos de Coruja, Requiem has a first-person female narrator, Catarina, a young Chinese woman from Batavia (now Jakarta). The daughter of a wealthy continental Chinese merchant, she becomes engaged to the captain of the port of Dili, a union arranged to seal the two men's commercial association. When the business threatens failure, her father sends her to Dili unannounced, to rehabilitate the coffee plantation in question. A beautiful young woman with a first-rate "European education" (12), she carries a book with her: Alain Gerbault's record of his circumnavigation, A la poursuite du soleil-an ominous choice, given Gerbault's death in Dili's harbour in December 1941, just before the Japanese invasion. Suspected of spying both for the Japanese and the Dutch (163), Catarina moves to Gerbault's yacht at the end of the novel, when her house is set on fire, her story thus ultimately intertwined with her hero's. 
Although the novel concentrates on Catarina's loves and determination to survive in Timor, there is a clear preoccupation with historical detail, chronologically presented: first, the pacification of the territory and (enforced) development of coffee cultivation under Governor Celestino da Silva (13); ${ }^{14}$ then, the policy of dumping Portuguese non-conformists on the island, where they were to guard others overtly exiled (14); next, the Japanese Tanaka Plan to occupy the Far East, which reminds Catarina of her family history, during the Japanese invasion of Manchuria (14), and prompts a mildly critical reflection: "A história é fértil em exemplos de más interpretações" [history is full of examples of misinterpretations] (14), possibly hinting at Timor's later history. Catarina's marriage is set for the year in which rust ruined the coffee plantations (17). At this point the narrative shifts to Catarina's personal story, but with later references to the Spanish Civil War, Hitler and the war the Timorese hope will not reach their island (78), as well as to the abuses by Portuguese authorities against local populations and deportees (80), and to the Japanese push into Nanking (89-90). History is thus never absent from these pages.

The art of storytelling is here coloured with an unapologetically Oriental(ist) hue, as befits the narrative of a young Asian woman of the 1940s, who dreams of her "prince charming" (11 ff.) and knows the power of her beauty. Once again, the fictional point of departure is immediately captivating: no blindfold, but an alluring gesture by the groom-to-be. He gives her a cat, "Alberto, o Abissinio." The captain of the port of Dili will never honour the agreement, and Catarina never marries, but other men will bring her other cats, each with a name and a nickname. Cats thus punctuate her personal story. It is only toward the end of the novel that Catarina understands the meaning of these successive gifts, instead of the flowers she desires: "Gatos davam-se às amantes, flores às meninas" (165) [cats were given to lovers/mistresses, flowers to young ladies]. Catarina, then, has come to belong to the social group known as nonas (191, 196), the name given in Timor to the concubines of European, or occasionally Chinese, men living on the island, whom nobody trusts. Hence the suspicion that she is a spy. Such relationships, highly censured, are a recurrent motif in Cardoso's fiction: there is a hint about it in the unofficial explanation for the Manufahi wars already mentioned (the Portuguese administrator's coveting of Dom 
Boaventura's fair-skinned wife), and in his forthcoming novel, $O$ Ano em que Pigafetta Completou a Circum-Navegação (2013), a central female character is in a similar situation, becoming a concubine because of the Indonesian invasion.

Historical setting and storytelling technique combine to provide illustration for a point made subtly but firmly throughout the novel. Faced with the imminent Japanese invasion, the Timorese eagerly await the arrival of reinforcements aboard a Portuguese ship that they know has sailed from Lisbon (152). But the ship does not arrive, probably because its troops are lingering deliberately, hoping to be marooned at sea when war breaks out. Essentially it is a hopeless wait on Dili's beach for a ghost-ship. Analogously, like a new Madama Butterfly, Catarina waits eternally at her bougainvillea-covered terrace. Then chapter XII starts with the announcement: “-Chegou o fantasma / que julguei ser o navio português" (157) [-The ghost has arrived / which I took to be the Portuguese ship]. But the ghost who arrives is the emaciated Alain Gerbault. While the motif of the ghost-ship is frequent in Cardoso's fiction, here it provides the link between fiction and history: the private life of a woman deserted by her fiancé mirrors the abandonment of Timor by the Portuguese during the Japanese invasion and (extra-diegetically) during the Indonesian one. Besides, the motif is also firmly entrenched in Timor's imaginaire, following the disappearance of the Arbiru en route to Singapore in $1973 .{ }^{15}$ A recent addition to local legend, it is nonetheless a fiction that responds to Timor's cultural beliefs.

Finally, another novel appeared in the same year as Luís Cardoso's Requiem: Domingos de Sousa's 2007 Colibere. The author has also published a non-fictional prison diary. This novel, with its strong emphasis on recording the nation's contemporary history for those too young to remember, testifies to his enduring interest in education, his area of tertiary specialisation, and in keeping history alive.

Colibere begins towards the end of Portuguese colonialism, in a hamlet in Manatuto, where living conditions are almost feudal, and a fatalistic worldview (9) removes all hope for improvement. It starts with long descriptions of the ceremonies involved in a traditional arranged marriage. The style is very didactic, even quoting at length from published anthropological studies, providing a fascinating picture of a ferociously traditional, rural Timor. These 
pages read more like cultural anthropology than fiction. Nevertheless, they provide essential clues about historicity and storytelling: the couple's son, Colibere, attends primary school but, accustomed to the oral tradition, it is through the stories he hears that he learns of Timor's history; and through the songs $(54,56,59)$ of the new political parties he grows aware of political change. Social change comes as a cultural shock when Indonesian murders and other crimes go unpunished unlike in Timorese society (73). Eventually Colibere joins the resistance, is arrested by the Indonesians and deported to the island of Ataúro, enduring hunger, humiliation, and torture, until he descends into madness. Set free, he continues to live in sub-human dejection. The novel narrates mass killings, rapes, executions by Indonesian troops, the Santa Cruz massacre, the referendum, and the bloodbath that followed, ending with the enthusiastic support for the National Council of Timorese Resistance, and hope's return, all seen through Colibere's largely uncomprehending eyes.

Although the narrative technique is uneven, this is a remarkable record of Timor's contemporary history, interwoven with the story of a fictional character that becomes one of its most pitiable victims. Domingos de Sousa portrays the convulsions of Timorese society in the twentieth century, with a distinctive, austere and edifying voice. Just like Ponte Pedrinha's protagonist, Colibere stands for all the anonymous Timorese heroes and heroines who contributed to the construction of their nation against all historical odds. And just like Ponte Pedrinha's novel, Colibere offers a deeply Christian viewpoint, which is at the core of Timorese culture.

Each of the books here studied reveals an unquestionable preoccupation with historicity_seamlessly combined, in Luís Cardoso's case, with masterly storytelling, with Ponte Pedrinha and Domingos de Sousa still searching for a fluent fictional voice. In Ponte Pedrinha's novel, we must take the central role assigned to Christian faith as an integral part of historicity. As Alexander Loch has shown, at village level Catholic values must always be taken into account because Timorese people's priorities are "First the [sacred] house, then the Church, and finally a modern state" (104). Domingos de Sousa's Colibere comes closest to being a straightforward historical novel, in that it respects the chronology of the events that have marked Timor-Leste's emergence as a nation. 
Then again, it also teems with the myths and rituals of Timor's ancestral world, normally out-of-place in historical novels. To my mind, the narrator's sternness and tendency to express moral judgements add a strong note of political intervention to Colibere, but they also represent fictionally the gravitas of Timorese old men. Luís Cardoso's work stands out for its fictional inventiveness and its remarkably penetrating understanding of the dilemmas that confounded Timorese of all factions in the late twentieth century. In his novels fact and fiction play inextricably together. The author incorporates his extended knowledge of academic history as well as his country's ancestral beliefs, customs, myths, and oral history, with a charming lightness of touch in his storytelling. He often engages with the tricky mechanisms of identity, speaking of colonialism without rancour but leaving no room for doubt about the Timorese roots of his imagination.

Above all, these novels tell stories deeply immersed in the Timorese cultural universe, and they narrate the history of Timor-Leste through fiction-as does Timor-Leste's oral tradition. Although there are postmodernist features in some of Luís Cardoso's novels, particularly when he engages critically with Portuguese colonial history, these novelists' endeavour seems to be: not so much to rewrite history from a Timorese perspective, but rather to dispel the lies that world politics and the media (rather than academic history) wove around their contemporary history. They seem less concerned with questioning the knowledge of their country's colonial past (taken by and large as a historical given) than with actually writing the history of their nation's birth. They do question the lies fabricated about the Indonesian annexation and prove them wrong, but there is no postmodernist presentation of conflicting truths-claims. In these novels, there is an urgent need to tell the truth-but fortunately above all through most enticing storytelling. As Julia Alvarez explains in the postscript to her In the Time of Butterflies, "A novel is not, after all, a historical document, but a way to travel through the human heart" (324). 


\section{Notes}

1 Indonesian, which displaced Portuguese in the years between 1975 and 1999, is recognised as a working language, as is English.

2 This was a project created by Australian John Holdaway to encourage literary writing in Tetum, especially amongst young people. Holdaway also assisted Teo Ximenes in selfpublishing his manuscript, and he later secured funding to ensure continuity of the project.

3 Elsewhere I have analysed some of the poetry in Portuguese (Moutinho, "A New Dawn"), and Leigh-Ashley Lipscomb has studied some poems in Tetum. As to the stories and (very) short novels written in Tetum, my linguistic shortcomings do not yet allow me to appreciate them. They belong to a future project.

4 Luís Cardoso was studying in Portugal with a much-coveted scholarship when the invasion took place, preventing him from returning home. Domingos de Sousa and Henrique Borges (Ponte Pedrinha's real name) were forced to leave their country together with their families as a result of the invasion.

5 Wherever possible, quotations are taken from the published English translation, The Crossing, by Margaret Jull Costa, with only the page number given in brackets. Quotations indicated as (Travessia) refer to the Portuguese original. All other translations in this study are mine.

6 Both parties wanted independence for Timor, but Fretilin wanted it immediately, while UDT advocated an extended period of transition under Portuguese administration.

7 As already mentioned, Ponte Pedrinha is a pseudonym. In the novel, it is also the name of the street where the disappeared protagonist's wife lives (181).

8 Sources about numbers of speakers of the various Timorese languages vary considerably. Mambai may have been more widely spoken than Tetum in 1982, when the Catholic Church adopted the latter.

9 Salazar is referred to as "the lord of the empire" (141), or "the lord of São Bento" (124); but his birthplace, Santa Comba Dão, provides Father Santa's name. São Bento is the location of the Portuguese National Assembly, of which Father Santa is "a notable member [...] for the Province of Timor" (132).

10 Fictionally, the novel entertains the possibility that the narrator and her husband are the ghosts of her grandparents (158). Also, many people attend the girl's baptism, "inclusive pessoas que tinham morrido durante as guerras" (114) [including people who had died during the wars]. In both cases, the humour is evident, although the presence of spirits in isolated places is presented as normal in Timorese beliefs.

11 Olhos 127: "fez-se baptizada pelo padre Santa (...) porque senão não teria identidade nem passaporte, teve de aprender a ler e a escrever."

12 Cardoso explains the "rank" in his Requiem para o Navegador Solitário (65): "darlhe em troca da sua rendição [...] o título honorífico de coronel de segunda linha, com direito a pensão vitalícia e casa posta" [to give him, in exchange for his surrender, the honorary title of second line colonel, complete with a pension for life and a house set up for him].

13 Some Timorese wanted the Portuguese to return in 1975 because then they would recover the rank of "coronel de segunda linha" and collect all the back-pay due since their departure, just as García Márquez’s colonel endlessly waits for his pay check to arrive.

14 See Shepherd and McWilliam for the way the Timorese had to be "moulded" to suit the economic aspirations of the Portuguese, particularly in regard to coffee plantations. 
15 In the forthcoming O Ano em que Pigafetta Completou a Circum-Navegação there is ample reworking of this motif and the concomitant myth of the return of a "live-ghost." This is an outstanding novel, which calls for detailed analysis elsewhere, as soon as it is published.

\section{Works Cited}

Alvarez, Julia. In the Time of the Butterflies. Chapel Hill, NC: Algonquin Books of Chapel Hill, 1994. Print.

Cardoso, Luís. Crónica de Uma Travessia. A Época do Ai-Dik-Funam. Lisbon: Publicações Dom Quixote, 1997. Print.

—. The Crossing. A Story of East Timor. Trans. Margaret Jull Costa. London: Granta, 2002. Print.

—_. Interview with Ramon Mello. "Luís Cardoso e o Desafio de Escrever a partir de uma Voz Feminina." Saraiva Conteúdo. 29 May 2010. Web. 31 Jan 2013.

—. Olhos de Coruja Olhos de Gato Bravo. Lisbon: Publicações Dom Quixote, 2001. Print.

—. Requiem para o Navegador Solitário. Lisbon: Publicações Dom Quixote, 2007. Print.

—. A Última Morte do Coronel Santiago. Lisbon: Publicações Dom Quixote, 2003. Print.

Clendinnen, Inga. Reading the Holocaust. Melbourne: Text Publishing, 1998. Print.

Esperança, João Paulo T. "Um Brevíssimo Olhar sobre a Literatura de Timor." O Que é a Lusofonia?/ Saida maka luzofonia. Díli: Instituto Camões, 2005. 42-50. Print.

Gomes, Nuno da Silva. "A Literatura Popular de Tradição Oral em Timor-Leste." Unpublished M.A. thesis, University of Minho, 2007. Lisbon: Biblioteca Nacional. Microfilm.

Hutcheon, Linda. A Poetics of Postmodernism: History, Theory and Fiction. New York: Routledge, 1988.

Lipscomb, Leigh-Ashley. "Post-independence Timorese Literature and the Aesthetics of Accountability." Hatene kona ba/ Compreender/ Understanding/ Mengerti Timor-Leste Conference, 2-3 July 2009, UNTL, Dili. Ed. M. Leach, N. C. Mendes, A. B. da Silva, A. d. C. Ximenes and B. Boughton. Hawthorn: Swinburne Press, 2010. 168-173. Print.

Loch, Alexander. "Nation Building at the Village Level: First the House, then the Church and Finally a Modern State." East Timor: How to Build a New Nation in Southeast Asia in the 21st Century? Ed. Christine Cabasset-Semedo and Frédéric Durand. Bangkok: IRASEC, 2009. 95-104. Print.

Lucáks, Georg. The Historical Novel. Trans. H. and S. Mitchell. London: Merlin Press, 1962. Print.

Moutinho, Isabel. “The Fractured Affair of East Timorese Ident/ities.” Parts of Asia, Special Issue of Portuguese Literary \& Cultural Studies 17/18 (2010): 357-371. Print.

"A New Dawn at the Edges of the Pacific: The Rising Literature of East Timor." Littératures du Pacifique insulaire en langues européennes. Ed. Sylvie André and Jean Bessière. Paris: Editions Honoré Champion, In Press. 175-203. Print.

Pedrinha, Ponte. Andanças de Um Timorense. Lisbon: Colibri, 1998. Print.

Sá, António Basílio de. Textos em Teto da Literatura Oral Timorense. Lisbon: Junta de Investigação do Ultramar, 1961. Print. 
Shepherd, C. J. and A. McWilliam. "Divide and Cultivate: Plantations, Militarism and Environment in Portuguese Timor, 1860-1975." Comparing Apples, Oranges, and Cotton: Environmental Histories of the Plantation. Ed. F. Uekoetter. New Haven: Yale UP, forthcoming. Print.

Sousa, Domingos de. Colibere: Um Herói Timorense. Lisboa: LIDEL, 2007. Print.

Therik, Tom. "The Role of Fire in Swidden Cultivation: a Timor Case Study." Inland Saline Aquaculture: Proceedings of a Workshop held in Perth, Western Australia, 6-7 August 1997. Ed. Barney Smith and Chris Barlow. Canberra: ACIAR (Australian Centre for International Agricultural Research), 1999. 77-80. Print.

Timor Aid. "Manan na'hin iha kompetisaun Istoria Timor/Winners of Istoria Timor." Weblog entry. Istoria-Timor. 6 Sept 2010. Web. 31 Jan 2013.

Traube, Elizabeth G. Cosmology and Social Life: Ritual Exchange among the Mambai of East Timor. Chicago and London: U of Chicago P, 1986. Print.

—. "Obligations to the Source: Complementarity and Hierarchy in an Eastern Indonesian Society." The Attraction of Opposites: Thought and Society in a Dualistic Mode. Ed. David Maybury-Lewis and Uri Almagor. Ann Arbor: U of Michigan P, 1989. 321-43. Print.

Tutikian, Jane. “Lucas Santiago: Uma Personagem Pós-colonial." Letras de Hoje 41: 3 (September 2006): 149-158. Porto Alegre. Print.

Isabel Moutinho lectures in the Spanish

Program, La Trobe University, Australia. She is

the author of The Colonial Wars in Contemporary

Portuguese Fiction (2008), co-edited The Paths

of Multiculturalism (2000), and has published

extensively on contemporary Portuguese literature

and culture, postcolonial literatures in Portuguese,

globalisation and literature, cultural memory and

identity. Her current research focuses on tracing the emergence of narrative fiction in Portuguese in Timor-Leste. 